\title{
Household Attributes in a Transit-Oriented Development: Evidence from Taipei
}

\author{
Jen-Jia Lin, National Taipei University \\ Ya-Chun Jen, Taiwan Ministry of Finance
}

\begin{abstract}
This empirical study of the Metro Danshui Line in Taipei analyzed the attributes of households residing in "areas with significant attributes of TOD built environment" $\left(T O D^{+}\right)$by applying a questionnaire survey and binary logit model. The empirical results were the following: household income, household size, and floor space needs are negatively associated with $\mathrm{TOD}^{+}$; the presence of children or elderly family members and preference for dense development, mixed land use and public facilities are positively related to $\mathrm{TOD}^{+}$. Based on the empirical findings of this study and the objective of deploying TODs near metro stations, general strategic directions for land use planning and property marketing are recommended to government agencies and real estate developers.
\end{abstract}

\section{Introduction}

Suburbanization and planning unit development have encouraged dependence on private automobiles in North America since the 1930s. Neighborhood designs with large-scale blocks, sparse arterial networks, and cul-de-sacs reduce the inclination to walk and the development of transit services. Such automobile-based development tends to cause urban sprawl, increase commuting distance, and reduce land use efficiency. Since transit systems promote the efficient use of resources such as 
land, fuel, etc., cities are increasingly applying transit-based strategies to enhance urban sustainability. Transit-oriented development (TOD) is now a popular strategy in North America for shaping transit-based spatial structures.

Taiwan has experienced rapid population and economic growth since the end of World War II but has extremely limited land resources. Automobile-based development in recent decades has caused substantial transportation inefficiencies and environmental degradation. To reduce traffic congestion and improve environmental quality, cities in Taiwan are now applying TOD principles in their urban development strategies. For instance, Taipei, the largest city in Taiwan, announced a comprehensive TOD plan (Department of Urban Development of Taipei City 1999) and a revised zoning ordinance to encourage dense development near metro stations by raising the maximum allowable building-bulk ratio.

Dense development, mixed land use, and pedestrian-friendly design are principle attributes of the TOD built environment and are associated with numerous benefits for urban sustainability (Cervero et al. 2004). However, some attributes may be undesirable to the general public. Residents often prefer low density and pure residential environments, which are incompatible with an environment of dense and diverse land uses. Senior, Webster, and Blank (2004) investigated households in the Cardiff region of South Wales and concluded that most relocating households prefer, and actively seek to move to, detached or semi-detached housing with private gardens, often in suburban locations. Apartment living is rarely preferred, and access to facilities in mixed land use areas is rarely a major concern. Thus, urban planners should not assume that residents prefer a TOD built environment.

Previous studies of TOD mostly focused on government concerns such as planning strategies and implementation (Banai 1998; Beimborn et al. 1991; Cervero 1994; Loukaitou-Sideris 2000; Moon 1990), planning models (Kaneko and Fukuda 1999; Lin and Gau 2006; Lin and Li 2008) and effect assessment (Cervero and Arrington 2008; Lund et al. 2004; Lin and Shin 2008). Property markets and developers in TOD areas are rarely analyzed. For instance, Cervero and Bosselmann (1994) found that property developers were uninterested in developing transit villages and dense communities in the San Francisco Bay Area, and Levine and Inam (2004) reported that local regulation, neighborhood opposition, and lack of market interest are the three main obstacles to TOD. Further, few studies have explored housing demand in TOD. Lund (2006) surveyed the motivations of residents for living in a TOD area and found that type or quality of housing, cost of housing, and quality of neighborhood were the top three considerations of residents who 
had chosen to live in a TOD. The Lund study of TOD focused on why, instead of who. Although Arrington and Cervero (2008) compiled fragmentary evidence of TOD resident characteristics, very few previous studies have compared resident characteristics between TOD communities and general communities. However, understanding household attributes of TOD residents is essential for deploying TOD successfully via market mechanisms.

This study empirically analyzed correlations between household attributes and the decision to live in a TOD built environment by applying binary logit model to survey data for 388 households near metro stations in Taipei. The empirical findings of this work provide a basis for recommending possible TOD planning strategies given considerations of property demand. The paper is organized as follows. Section 2 describes the research design, including assessment of survey areas, hypothesized relationships, and data analysis methods. Section 3 describes the sample data. Section 4 presents the model estimations and recommended strategies. Conclusions are presented in Section 5 along with recommended future research.

\section{Research Design}

\section{Survey Area Selection}

This study first selected two metro station areas that significantly differed in terms of TOD built environment. The Taipei Danshui Line originally served as an ordinary railway between 1901 and 1988 before it was incorporated into the Taipei metro system in 1997. Because the land use development along the line has been stable, the areas near Danshui Line stations were selected for survey in this study. Two areas were selected: areas with significant attributes of TOD built environment $\left(\mathrm{TOD}^{+}\right)$and areas with attributes contrary to TOD built environment (TOD). A station area was defined as the area within a quarter mile (about 400 meters) of a metro station, as in earlier works by Calthorpe (1993), White and McDaniel (1999), and Lin and Gau (2006). Following survey area selection, sample households were selected and investigated. Factors affecting the decision to live in a TOD area and household attributes were recorded for each observation. Two phases of living area choice were analyzed: present choice and future choice. To control for transportation and buffer attributes that could affect residential location choices, the two station areas were selected for analysis because of their locations along the same metro line and their differences in TOD built environment attributes. The Metro Danshui Line is $22.8 \mathrm{~km}$ long and connects the city center with the northern 
suburban township of Danshui. Twenty station areas along the metro line were assessed. The following four criteria were used to assess built environment of TOD ${ }^{+}$ in the analyzed areas, based on the recommendations of local studies in Taiwan, including Chang et al. (2000), Huang (2002), and Zhuo (2004): (1) number of land use types, for measuring land use diversity in a station area; (2) area ratio of floor space to land, for measuring land use density in a station area; (3) length ratio of sidewalks wider than $2 \mathrm{~m}$ to length of all sidewalks, for measuring pedestrian friendliness in a station area; and (4) number of public facility types, for measuring sufficiency of public facility supply in a station area.

As Fig. 1 shows, the Xinbeitou station area $\left(\mathrm{TOD}^{+}\right)$and the Guandu station area (TOD) were selected by applying the above four criteria. Xinbeitou had the highest ranking of public facilities and the second and sixth highest rankings for other cri-

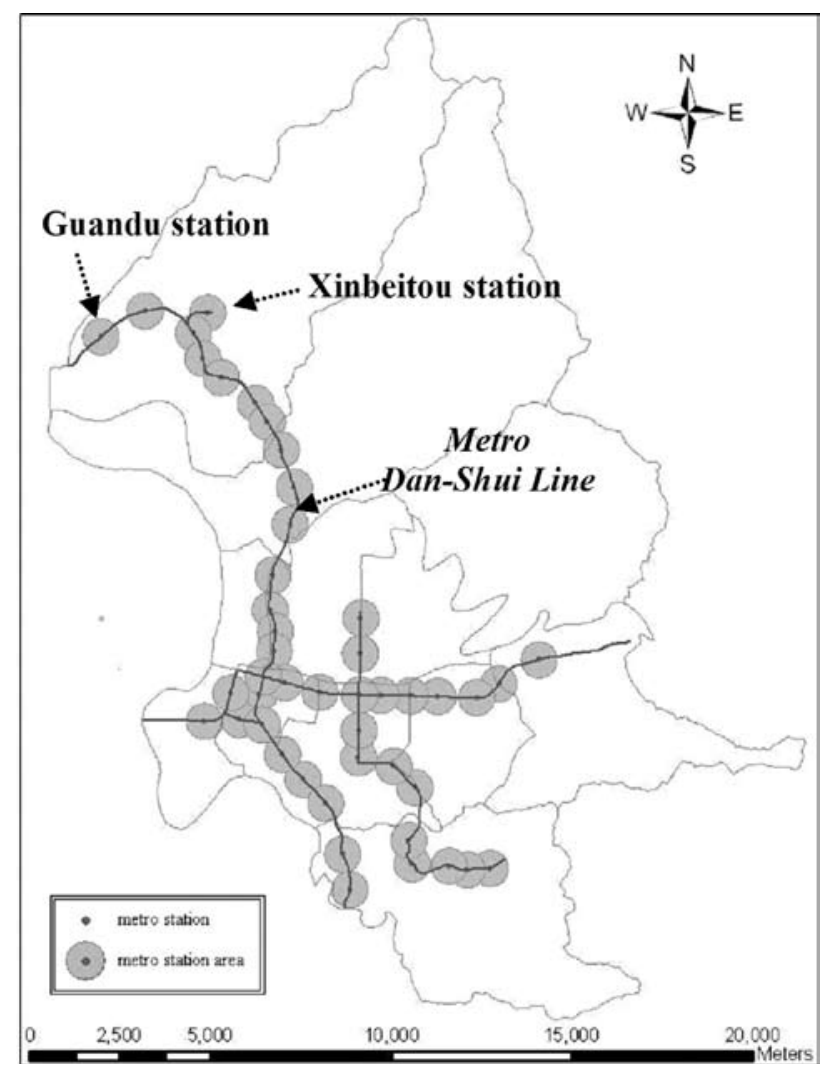

Figure 1. Location of Survey Areas in Taipei City 
teria, while Guandu has the second or third worst rankings for all criteria. Further, Xinbeitou ranked significantly higher than Guandu in all criteria. Table 1 compares the two station areas. Both stations had been in service since the ordinary railway era, and both were located in Beitou District, a suburban residential community in Taipei with a long development history. Land use in the Xinbeitou station area is designated as a mixed residential and commercial facility, and Xinbeitou has been promisingly and densely developed as a residential and recreational area for 100 years because of its hot springs resources. The Guandu station area was traditionally an agricultural village for hundreds of years before being developed as a residential community just 20 years ago. As a newly developed community, the Guandu station area has large blocks, wide arterials, and ample parking because urban planning and building design in recent years have been mostly automobilebased. Apartments are the major property style in both areas. Dwelling units in Xinbeitou are small to medium in size (33 to $100 \mathrm{~m}^{2}$ ), while those in Guandu are medium to large in size (100 to $200 \mathrm{~m}^{2}$ ). Property price per dwelling unit in Xinbeitou is lower than that in Guandu because of size and building age differences.

\section{Table 1. Comparisons of Survey Areas, end of 2005}

\begin{tabular}{|c|c|c|}
\hline Attributes & Xinbeitou (TOD ${ }^{+}$) & Guandu (TOD') \\
\hline \multicolumn{3}{|l|}{ Differences } \\
\hline Number of land use types & 26 & 20 \\
\hline Area ratio of floor space to land & $110.86 \%$ & $66.90 \%$ \\
\hline $\begin{array}{l}\text { Length ratio of sidewalks wider } \\
\text { than } 2 \mathrm{~m} \text { to all sidewalks }\end{array}$ & $69.47 \%$ & $48.65 \%$ \\
\hline Number of public facility types & 21 & 8 \\
\hline Population density & 0.0246 people $/ \mathrm{m}^{2}$ & 0.0155 people $/ \mathrm{m}^{2}$ \\
\hline \multicolumn{3}{|l|}{ Typical property supply } \\
\hline Floor space per dwelling unit & $33-100 \mathrm{~m}^{2}$ & $100-200 \mathrm{~m}^{2}$ \\
\hline Type & $\begin{array}{c}\text { Apartment, } 4-5 \text { floors \& } \\
\text { high building coverage ratio }\end{array}$ & $\begin{array}{l}\text { Apartment, } 7-10 \text { floors \& } \\
\text { low building coverage ratio }\end{array}$ \\
\hline Price per dwelling unit & 2-6 millions NT\$ & $>8$ millions NT\$ \\
\hline \multicolumn{3}{|l|}{ Similarities } \\
\hline Station area type & \multicolumn{2}{|c|}{ Residential community } \\
\hline Administration belongingness & \multicolumn{2}{|c|}{ Beitou District } \\
\hline Location & \multicolumn{2}{|c|}{ Suburban areas of Taipei } \\
\hline Settlement history & \multicolumn{2}{|c|}{$>100$ years (Xinbeitou is since 1880, Guandu is since 1640 ) } \\
\hline
\end{tabular}

P. S. 1 NT\$ $\cong 0.03$ US\$ in 2005 . 


\section{Hypothesized Relationships}

As Table 2 shows, four factors, including economy, member component, house demand, and environment preference, were employed to explain household decision to live in a $\mathrm{TOD}^{+}$area. Income is the main variable representing household economic status. High household income increases the choice of housing alternatives. Previous studies generally agree that high-income households tend to choose suburban or rural areas in which density is low, land use is purely residential, and environment is delicate (Earnhart 2002; Srinivasan and Ferreira 2002; Kim et al. 2005). Thus, we hypothesized that income is negatively associated with preference for $\mathrm{TOD}^{+}$, which is characterized by dense environment and mixed land use.

\section{Table 2. Hypothesized Relationships between Household Attributes and Choice of TOD ${ }^{+}$}

\begin{tabular}{|c|c|c|c|c|c|c|c|c|c|}
\hline \multirow[b]{2}{*}{$\begin{array}{c}\text { Household } \\
\text { Attributes }\end{array}$} & \multirow{2}{*}{$\begin{array}{l}\text { Economy } \\
\text { Income }\end{array}$} & \multicolumn{2}{|c|}{ Member } & \multicolumn{2}{|c|}{ House } & \multicolumn{4}{|c|}{ Environment Preference } \\
\hline & & Number & $\begin{array}{l}\text { Children } \\
\text { or Elders }\end{array}$ & $\begin{array}{c}\text { Price } \\
\text { Affordability }\end{array}$ & $\begin{array}{l}\text { Floor } \\
\text { Space } \\
\text { Needs }\end{array}$ & $\begin{array}{l}\text { Mixed } \\
\text { Land } \\
\text { Use }\end{array}$ & $\begin{array}{c}\text { Dense } \\
\text { Development }\end{array}$ & $\begin{array}{c}\text { Public } \\
\text { Facilities }\end{array}$ & $\begin{array}{c}\text { Pedestrian } \\
\text { Friendly } \\
\text { Facilities }\end{array}$ \\
\hline $\begin{array}{c}\text { Choosing } \\
\text { TOD }^{+}\end{array}$ & - & - & + & - & - & + & + & + & + \\
\hline
\end{tabular}

P. s.: +, positive effect; -, negative effect

Two variables were considered to denote member components of a household. Number of household members correlated negatively with residence in $\mathrm{TOD}^{+}$ because increasing family size requires larger floor area, and large houses are usually located in low-density suburban areas (Wee et al. 2002). Further, households with children or elders usually generate many non-work trips, so they tend to live in convenient, accessible, and mixed land use communities (Kim et al. 2005; Sermona and Koppelman 2001). Therefore, $\mathrm{TOD}^{+}$should be welcomed by households with children or elders.

Price affordability and floor space needs are the main concerns of families when choosing residential locations. High housing prices reduce the range of choices. Given equal transportation accessibility and equal household attributes, houses in TOD+ are usually priced lower than those in TOD- because the former tend to be located in dense and mixed land use zones. Further, households preferring large floor space tend to reside in low-density areas where the supply of dwelling units is larger than that in high-density areas (Kim et al. 2005; Sermona and Koppelman 2001). Thus, house price affordability and floor space needs are both expected to negatively impact the preference for living in $\mathrm{TOD}^{+}$. 
Finally, empirical data in previous studies, including Srinivasan and Ferreira (2002), Bhat and Guo (2004) and Kim et al. (2005), indicate that living environment affects residential location choices. Since different households have different living environment preferences, a household preferring dense environment, mixed land use, public facilities, or pedestrian-friendly facilities should have ample opportunity to reside in a $\mathrm{TOD}^{+}$area. The above variables were employed to explain the choice of $\mathrm{TOD}^{+}$, and Table 2 lists the hypothesized effects.

\section{Data}

To test the hypothesized relationships shown in Table 2, this study performed a questionnaire survey in March 2006. The survey population was 5,032 households residing in areas near the Xinbeitou and Guandu stations. Systematic random sampling was employed to select 1,200 households. Out of the 1,200 questionnaires distributed, 583 were returned (48.58\% response rate), of which 388 responses were effective (effective rate of $66.55 \%$ ). Incomplete questionnaires were excluded from the study sample. The sample contained 195 questionnaires returned by residents in the Xinbeitou station area (6\% sampling rate) and 193 questionnaires from Guandu station area (10\% sampling rate).

Figure 2 presents the sample data distributions of household attributes. Compared with the Guandu station area (hereafter TOD') residents, the Xinbeitou station area (hereafter $\mathrm{TOD}^{+}$) residents had lower monthly income, more years of residence, fewer household members, fewer children, and more elders. Figure 3 shows the distribution of sample data for environment preference. The preferences of the general sample regarding mixed land use and dense development were moderate, while preferences regarding pedestrian-friendly and public facilities were favorable or highly favorable. The TOD built environment attributes were not welcomed by all respondents. Compared with TOD observations, $\mathrm{TOD}^{+}$residents favored dense development, mixed land use, and public facilities but did not highly favor pedestrian-friendly facilities. Figure 4 shows that $\mathrm{TOD}^{+}$residents had lower housing costs and needed less floor space than TOD residents. Finally, Fig. 5 shows responses regarding preferences for future residential location. Most respondents indicated that they would choose a built environment similar to their current one. Restated, $\mathrm{TOD}^{+}$residents would choose $\mathrm{TOD}^{+}$and TOD residents would choose TOD. The preference for moving from $\mathrm{TOD}^{+}$to TOD was higher than that for moving from TOD to $\mathrm{TOD}^{+}$. Therefore, $\mathrm{TOD}^{-}$is apparently more attractive than $\mathrm{TOD}^{+}$as a residential location. 
A.

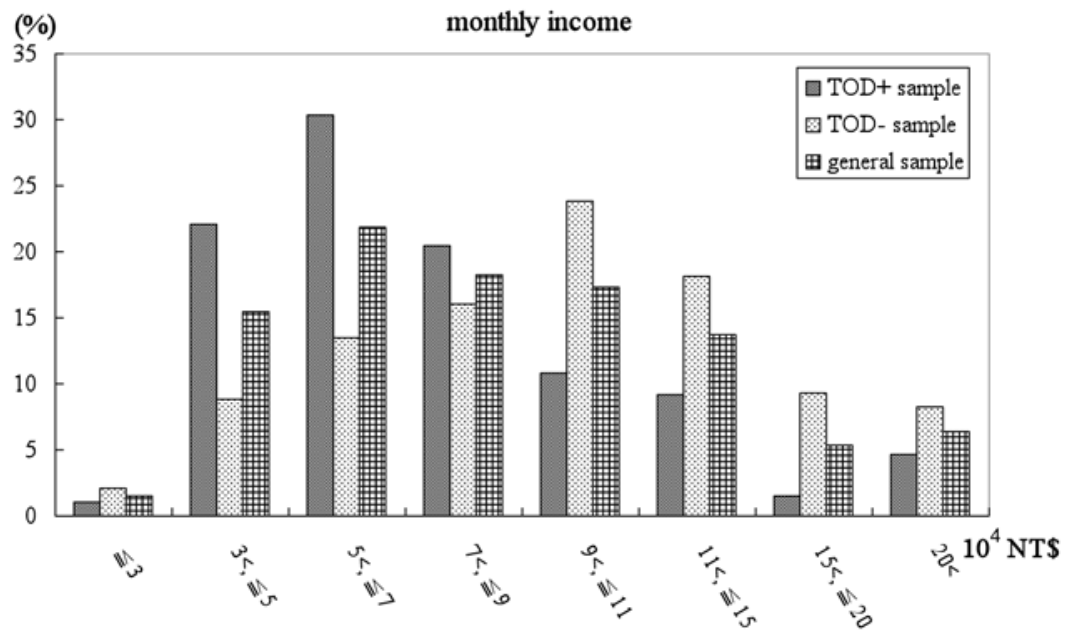

B.

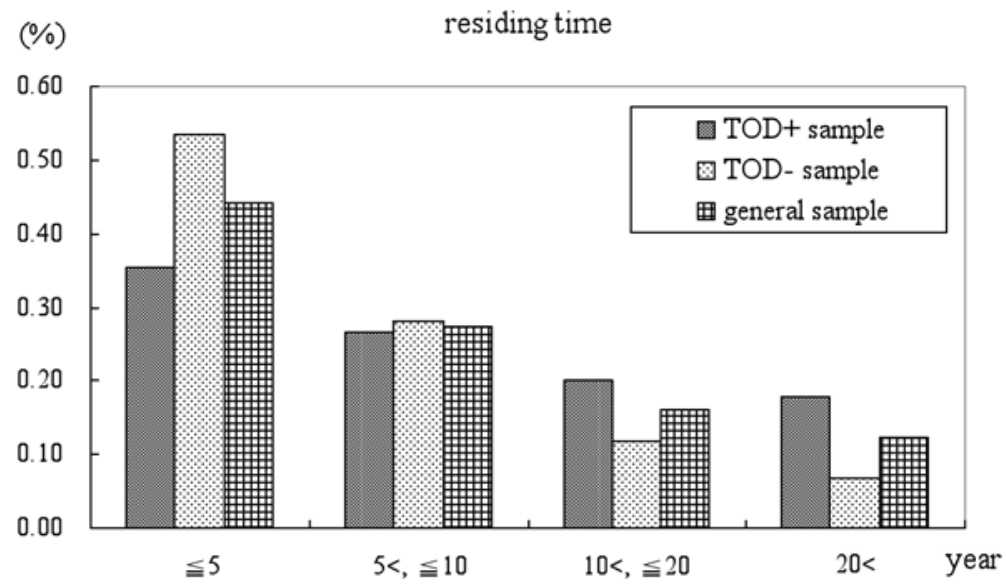

Figure 2. Sample Distributions of Household Attributes 
C.

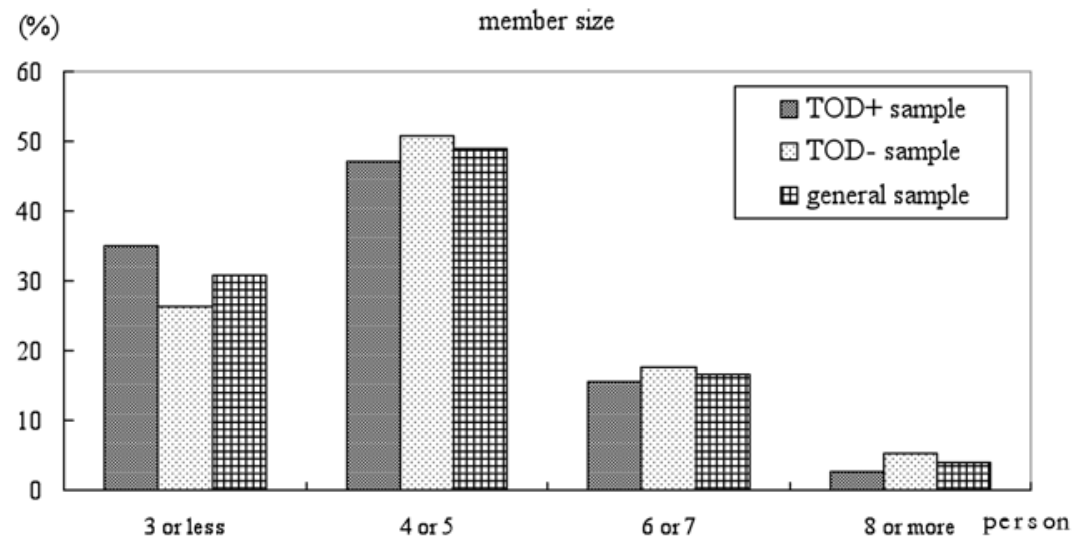

D.

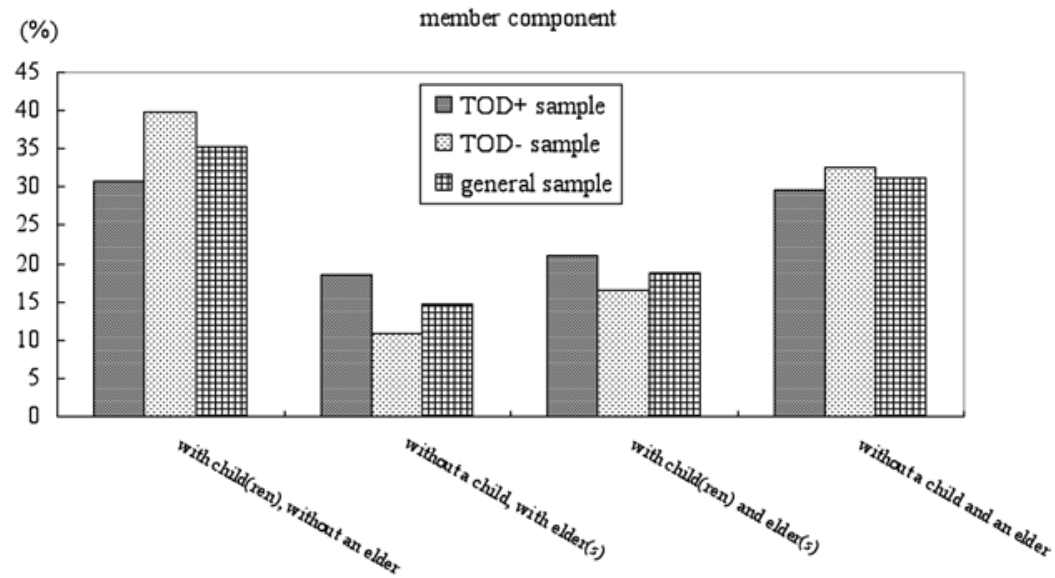

Figure 2. Sample Distributions of Household Attributes (cont'd.) 
A.

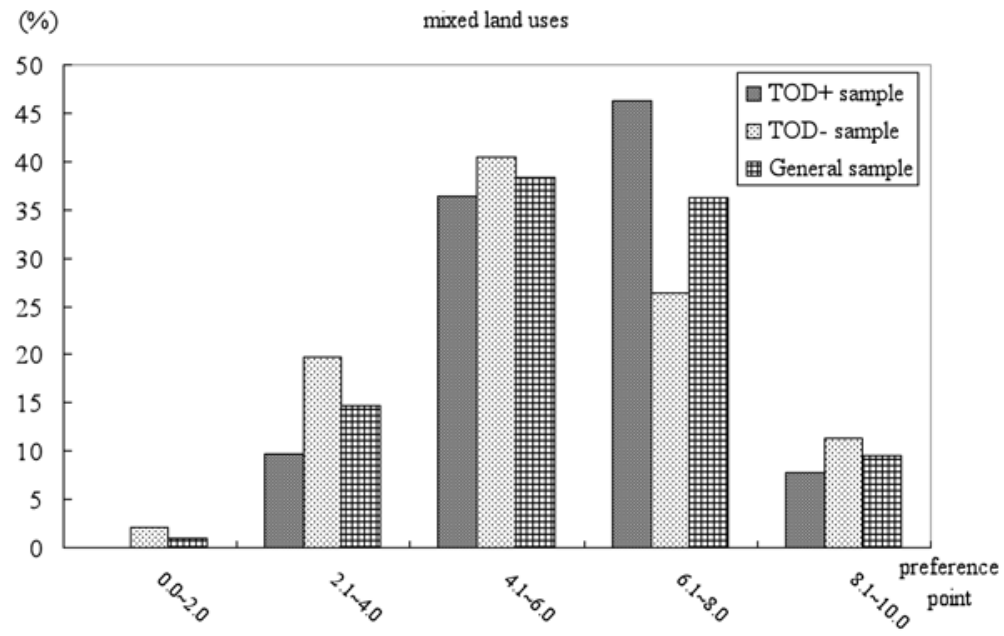

B.

(\%) dense development

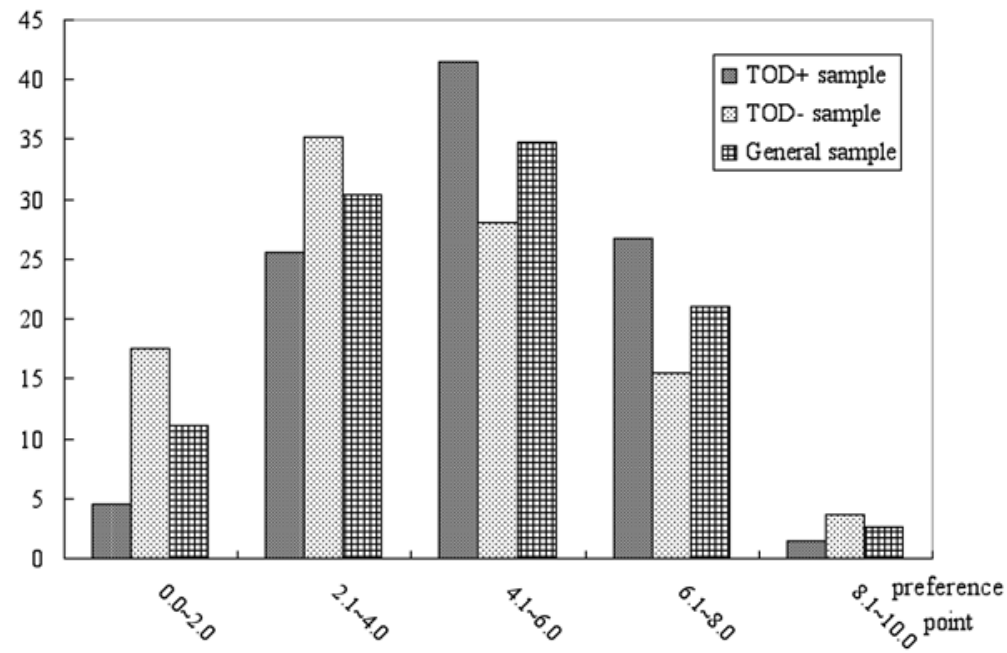

Figure 3. Sample Distributions of Environment Preferences 
C.

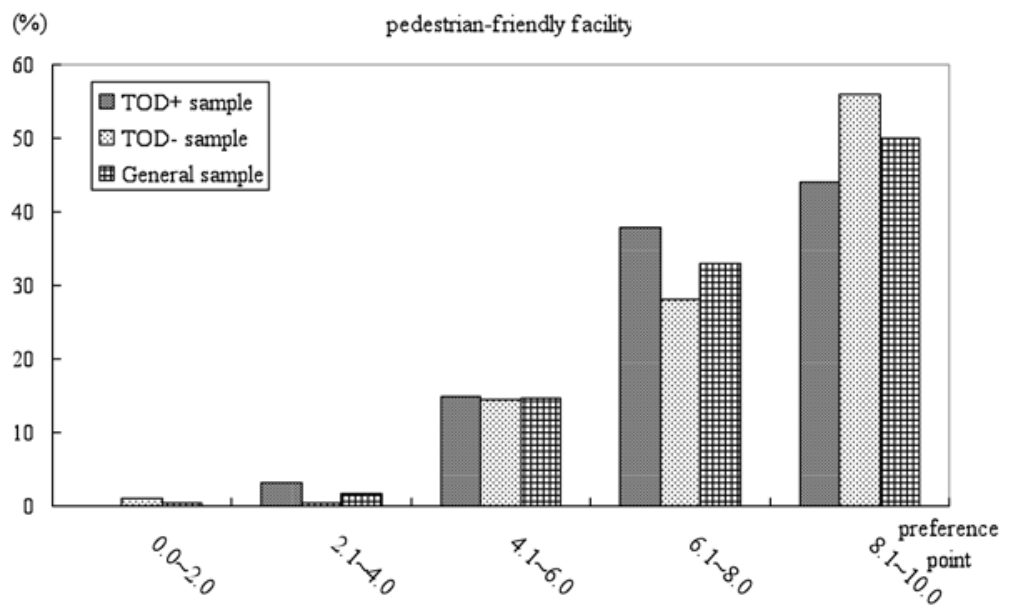

D.

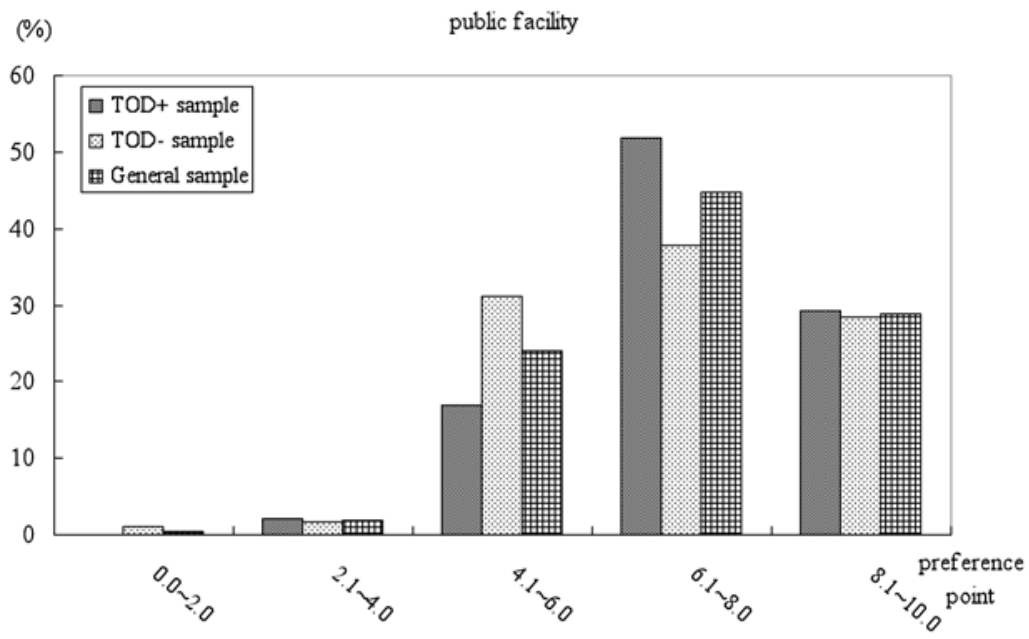

Figure 3. Sample Distributions of Environment Preferences (cont'd.) 
A.

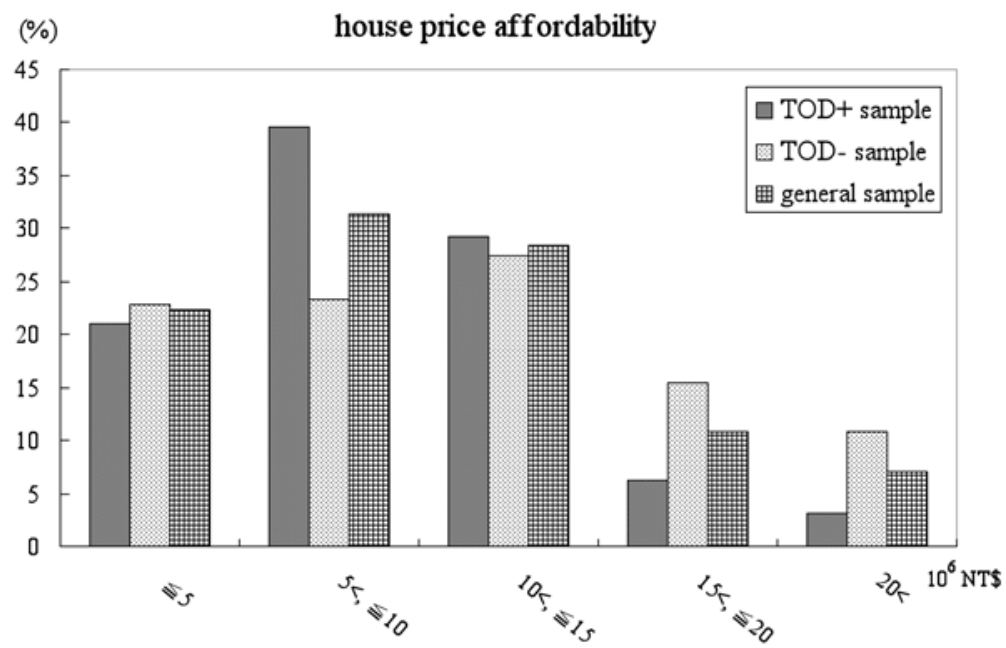

B.

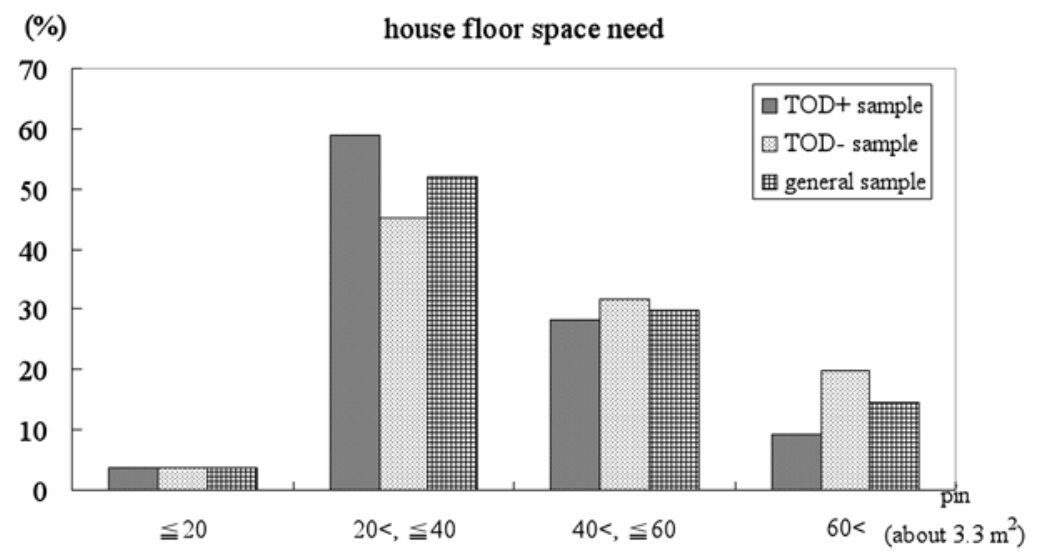

Figure 4. Sample Distributions of House Demands

The sample households had similar transportation services and had similar travel patterns. All sampled households were located within a quarter mile of a metro station, and all were served by more than 10 bus routes. Transit travel share was 23 percent for TOD residents and 26 percent for TOD ${ }^{+}$residents in 2001 (Department of Transportation of Taipei City 2001). Further, the sample area, the Beitou 


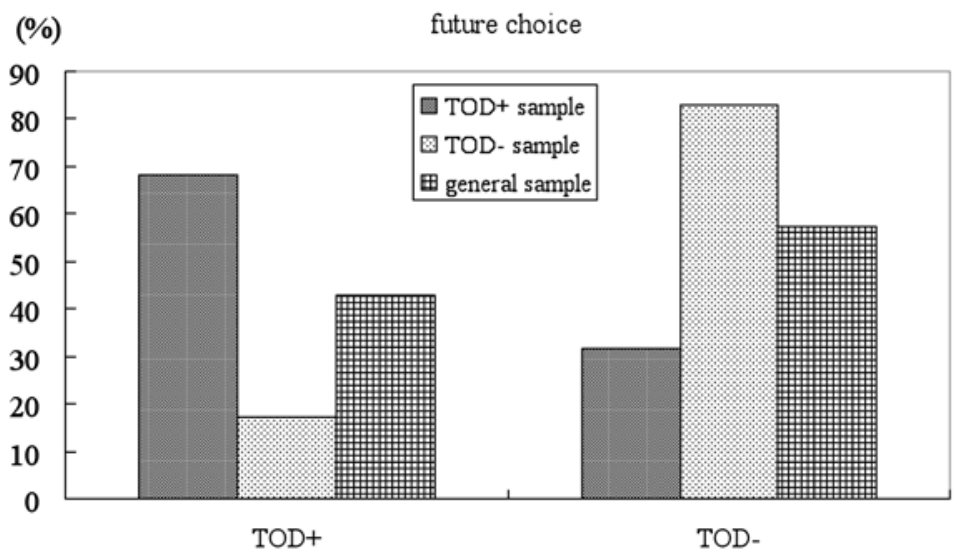

\section{Figure 5. Sample Distributions of Location Choice in Future}

District, had lower criminal case rate ( 137.6 cases $/ 10^{6}$ residents) than did Taipei City (205.0 cases $/ 10^{6}$ residents) in 2007 . The percentage of owner-occupied housing (88.35\%) was higher than the overall average for the city (81.02\%); the household income level $\left(1,44210^{3} \mathrm{NT} \$\right.$ /year) was lower than the overall average for the city $\left(1,52610^{3} \mathrm{NT} \$\right.$ /year) in 2006. In both sample station areas, weather conditions are similar. Ethnic or racial conditions are rarely essential considerations for residential location choice in Taiwan.

\section{Results}

\section{Model Estimations and Analysis}

Table 3 shows two models calibrated using Limdep 8.0 package. One model explains present choice, and the other explains future choice. The calibrated coefficients present the effects of independent variables on the decision to live in TOD ${ }^{+}$. Household income and member attributes were analyzed by dummy variables using "low income level" (less than 50,000 NT\$/month) and "without children or elders" as bases (i.e., all dummy variables are zero), respectively. The goodness-of-fit for each model was considered reasonable because successful forecast percentages were between 69 and 71 percent, and $\rho^{2}$ values were between 0.15 and 0.16 . 
Table 3. Estimation Results of Binary Logit Models $\left(\mathrm{TOD}^{+}=1, \mathrm{TOD}^{-}=0\right)$

\begin{tabular}{|c|c|c|}
\hline \begin{tabular}{|ll} 
Independent Variables & Models \\
\end{tabular} & $\begin{array}{c}\text { (1) } \\
\text { Present Choice Model }\end{array}$ & $\begin{array}{c}\text { (2) } \\
\text { Future Choice Model }\end{array}$ \\
\hline Constant & - & $-1.8033^{* * *}$ \\
\hline $\begin{array}{l}\text { Median-low income level } \\
50,000 \sim 89,999 \mathrm{NT} \$ / \text { month }=1\end{array}$ & - & $-0.3866^{*}$ \\
\hline $\begin{array}{l}\text { Median income level } \\
90,000 \sim 149,999 \text { NT\$/month = } 1\end{array}$ & $-1.0511^{* * *}$ & $-0.8405^{* * *}$ \\
\hline $\begin{array}{l}\text { High-income level } \\
150,000 \text { and more NT\$/month = } 1\end{array}$ & $-1.4238^{* * *}$ & - \\
\hline $\begin{array}{l}\text { Residing time } \\
\text { Unit: year }\end{array}$ & $\begin{array}{l}0.4110^{* * *} \\
(0.5687829)\end{array}$ & -- \\
\hline $\begin{array}{l}\text { Number of household member } \\
\text { Unit: person }\end{array}$ & $\begin{array}{l}-0.1492^{* * *} \\
(-0.298731)\end{array}$ & - \\
\hline With children and without elders $=1$ & $-\cdots$ & $-\cdots$ \\
\hline Without children and with elders $=1$ & $\ldots$ & $0.5495^{* *}$ \\
\hline With children and elders $=1$ & $0.5964^{* *}$ & - \\
\hline $\begin{array}{l}\text { House price affordability } \\
\text { Unit: } 10^{4} \mathrm{NT} \$ \text { per dwelling unit }\end{array}$ & - & - \\
\hline $\begin{array}{l}\text { House floor space need } \\
\text { Unit: pin, about } 3.3 \mathrm{~m}^{2}\end{array}$ & - & $\begin{array}{l}-0.1393^{* * *} \\
(-3.28863) \\
\end{array}$ \\
\hline $\begin{array}{l}\text { Preference for mixed land uses } \\
1 \sim 10 \text { points }\end{array}$ & - & $\begin{array}{c}0.3554^{* * *} \\
(1.232608)\end{array}$ \\
\hline $\begin{array}{l}\text { Preference for dense development } \\
1 \sim 10 \text { points }\end{array}$ & $\begin{array}{c}0.1558^{* * *} \\
(0.3309496) \\
\end{array}$ & - \\
\hline $\begin{array}{l}\text { Preference for public facilities } \\
1 \sim 10 \text { points }\end{array}$ & $\begin{array}{c}0.2568^{* * *} \\
(0.8448013) \\
\end{array}$ & $\begin{array}{c}0.2750^{* * *} \\
(1.157377) \\
\end{array}$ \\
\hline $\begin{array}{l}\text { Preference for pedestrian-friendly facilities } \\
1 \sim 10 \text { points }\end{array}$ & $\begin{array}{c}-0.2439^{* * *} \\
(-0.891469) \\
\end{array}$ & $\begin{array}{c}-0.2084^{* *} \\
(-0.97448) \\
\end{array}$ \\
\hline $\begin{array}{l}\text { Observations } \\
\text { Splits }\end{array}$ & $\begin{array}{c}388 \\
1: 50.3 \% ; 0: 49.7 \% \\
\end{array}$ & $\begin{array}{c}388 \\
1: 42.8 \% ; 0: 57.2 \% \\
\end{array}$ \\
\hline Successful forecast percentage & $69.1 \%$ & $71.4 \%$ \\
\hline $\mathrm{L}\left(\beta_{0}\right)$ & -226.2772 & -226.4236 \\
\hline $\mathrm{L}\left(\beta_{k}\right)$ & -268.9360 & -264.8857 \\
\hline$\rho^{2}$ & 0.16 & 0.15 \\
\hline$x^{2}$ & $85.31755^{* * *}$ & $76.92428^{* *}$ \\
\hline
\end{tabular}

P. S. ${ }^{* * *}$ significance in $\alpha=0.05,{ }^{* *}$ significance in $\alpha=0.1,{ }^{*}$ significance in $\alpha=0.2$; values in parentheses denote point elasticity values 
Using the calibrated model (1) in Table 3 to examine the hypothesized relationships in Table 2, the empirical data revealed the negative effects of household income and member size on the decision to live in $\mathrm{TOD}^{+}$and also showed that having children or elders as household members and the preference for dense development and public facilities were positively related to preference for living in $\mathrm{TOD}^{+}$.

However, house price affordability, house floor space needs, and preference for mixed land use were not significantly related to decision to live in $\mathrm{TOD}^{+}$. The insignificant results were due to the correlation of three variables: household income, household member size, and preference for dense development. Household income, household member size, and preference for dense development were positively associated with house price affordability, floor space needs, and preference for mixed land uses, respectively. Correlations among independent variables frequently revealed insignificant coefficients for some correlated variables. Accordingly, the effects of these three insignificant variables on the decision to live in $\mathrm{TOD}^{+}$were apparently supported but need further confirmation.

Further, preference for pedestrian-friendly facilities negatively affected the decision to live in $\mathrm{TOD}^{+}$, which is contrary to the hypothesized relationship. Figure $3 \mathrm{C}$ shows that respondents in the Guandu station area did have a slightly stronger preference for pedestrian-friendly facilities than did those in the Xinbeitou station area. Since this study evaluated station area using percentage of sidewalks wider than 2 meters and ignored sidewalk quality, the possible reason for the contrary result could be that the Guandu station area has better quality pedestrian facilities than does the Xinbeitou station area. Accordingly, the effect of preference for pedestrian-friendly facilities on decision to live in $\mathrm{TOD}^{+}$was unconfirmed and needs further study.

Comparing the results of model (2) with those of model (1) revealed that the effects of variables on future choice were similar to those affecting present choice. The two models revealed slight differences. Household income negatively affected the future decision to live in $\mathrm{TOD}^{+}$, but the significant effects of income levels decreased. Residing time and household member size significantly affected the present choice model but did not significantly affect the future choice model. The presence of elders in the household had greater explanatory power than the presence of children regarding the future decision to live in $\mathrm{TOD}^{+}$, while the presence of elders and children were both important in explaining present choice. Household member size and preference for dense development were significant in 
model (1) but insignificant in model (2). Because of the insignificance, house floor space needs and preference for mixed land uses, which correlated with household member size and preference for dense development, were significant factors in explaining future choice.

Table 3 lists point elasticity values of continuous variables for comparing the effects among variables and models. An elasticity value such as $e$ means that a one percent change in an independent variable is associated with an $e$ percent change in probability of choosing $\mathrm{TOD}^{+}$. Elasticity values in the future choice model exceeded those in the present choice model for all variables. In the present choice model, preferences for public and pedestrian facilities had the largest effect on the decision to live in $\mathrm{TOD}^{+}$while, in the future choice model, house floor space needs had the largest effect on decision to live in TOD ${ }^{+}$.

\section{Strategy Recommendation}

Based on the empirical evidence observed in this study, general strategies can be recommended for land use planning and property development to successfully deploy a TOD in a metro station area. Two strategic directions for land use planning are possible. First, since low-income and small-sized households, which prefer dense development, mixed land uses, and public facilities, tend to prefer living in $\mathrm{TOD}^{+}$, supplying dense and mixed land uses and public facilities needed by low income and small families around metro stations may be an effective strategy. Low income and small families usually prefer retail stores, restaurants, and daily services in popularized prices. To prevent increased density from negatively impacting the living environment, the development capacity for individual station areas should be identified and used as the upper bound for increased density. The compatibility of mixed land uses around metro stations also should be carefully evaluated for community amenity.

Second, because households with children or elders were found to prefer living in $\mathrm{TOD}^{+}$areas, facilities and services required by children and elders should be provided near metro stations. Children and elders commonly need parks, daycare/ schools, medical clinics, and nursing homes. Zoning regulations in station areas can be revised to attract $\mathrm{TOD}^{+}$residents by encouraging the above land uses. Besides land use planning and property development near metro stations, two other strategic directions are recommended. First, because low income households tend to live in $\mathrm{TOD}^{+}$, accessibly-priced residential properties should be developed near metro stations. Besides, households living in high-priced housing commonly have high income levels and seldom use public transit systems. Thus, developing 
high-price properties around metro stations is not associated with TOD since the interaction between properties and metro use is minimal.

Another suggested property development strategy is supplying small or medium dwelling units in multi-functional buildings or communities near metro stations. Because small-sized households and preferences for mixed land uses and public facilities are positively associated with living in $\mathrm{TOD}^{+}$, multiple property uses, including supermarkets, exercise centers, clinics, banks, bookstores, etc., in residential areas are not only welcomed by residents but can also economically benefit property managers.

\section{Conclusions}

To explore the attributes of households in a TOD built environment, this study performed a questionnaire survey of households in TOD ${ }^{+}$and TOD environments near metro stations in Taipei and calibrated binary logit models explaining the relationships between household attributes and the decision to live in $\mathrm{TOD}^{+}$. The empirical evidence indicated that household income, household member size, and floor space needs are negatively associated with a preference for living in $\mathrm{TOD}^{+}$, while the presence of children or elders and the preference for dense development, mixed land use, and public facilities are positively related to a preference for living in $\mathrm{TOD}^{+}$. Based on the empirical findings of this study and the objective of deploying successful TOD near metro stations, general strategic directions for land use planning and property development are recommended to government agencies and real estate developers.

Two limitations should be noted when applying the empirical findings and recommended strategies of this study. First, since the sample data were for residential communities, the results are more applicable to residential station areas than to urban areas such as commercial station areas. Second, because the surveyed areas were near guideway rapid transit stations, the results may be inapplicable to other transit systems such as bus systems.

To further clarify the real estate market in TOD, future research should investigate the following issues. First, this study focused on the demand side of the real estate market rather than the supply side. An understanding of both is needed to successfully and efficiently deploy TOD via market mechanisms. Thus, real estate developers in the examined areas require further study. Second, further various and detailed housing attributes are related to TOD resident preferences, such as 
housing type, building layout, and access design. The relationships between house attributes and these preferences is an important issue needing further study. Finally, besides the cross-sectional analysis in this study, a longitudinal study of residential location choices before and after developing the TOD built environment is essential to confirm the relationships between residential choice and TOD.

\section{References}

Arrington, G.B., and R. Cervero. 2008. Effects of TOD on Housing, Parking, and Travel. TCRP Report 128, Washington, D. C.: Transportation Research Board.

Banai, R. 1998. Transit-oriented development suitability analysis by the analytic hierarchy process and a geographic information system: A prototype procedure. Journal of Public Transportation 2(1): 43-65.

Beimborn, E., H. Rabinowitz, C. Mrotek, P. Gugliotta, and S. Yan. 1991. Transitbased approach to land use design. Transportation Research Record 1349: 107-114.

Bhat, C.R., and J. Guo. 2004. A mixed spatially correlated logit model: Formulation and application to residential choice modeling. Transportation Research Part B 38(2): 147-168.

Calthorpe, P. 1993. The Next American Metropolis: Ecology, Community, and the American Dream. New York: Princeton Architectural Press.

Cervero, R. 1994. Rail-oriented office development in California: How successful? Transportation Quarterly 48(1): 33-44.

Cervero, R., and G.B. Arrington. 2008. Vehicle trip reduction impacts of transitoriented housing. Journal of Public Transportation 11(3): 1-17.

Cervero, R., and P. Bosselmann. 1994. An Evaluation of the Market Potential for Transit-Oriented Development Using Visual Simulation Techniques. Berkeley: Institute of Urban and Regional Development, University of California, Monograph 47.

Cervero, R., S. Murphy, C. Feerell, N. Goguts and Y.H. Tsai. 2004. Transit-oriented Development in the United States: Experiences, Challenges, and Prospects. Transit Cooperative Research Program 102, Washington, D. C.: Transportation Research Board. 
Chang, S.K., S.T. Cheng and U.L. Tu. 2000. Transit-oriented strategies for urban development. Journal of Mass Rapid Transit Technology 22: 1-16. (In Chinese)

Department of Urban Development of Taipei City. 1999. Green and Ecological City Planning: General Review of Taipei City Master Plan. (In Chinese)

Department of Transportation of Taipei City (2001), Data Survey and Models Calibration for the Comprehensive Transportation Planning of Taipei Metropolitan Area. (In Chinese)

Earnhart, D. 2002. Combining revealed and stated data to examine housing decision using discrete choice analysis. Journal of Urban Economics 51: 143-169.

Huang, C.S. 2002. Transit Village Evaluation Model for Metropolitan Fringes. Master's degree thesis, Institute of Architecture and Urban Design, Chaoyang University of Technology. (In Chinese)

Kaneko, Y., and A. Fukuda. 1999. A location control model for transit-oriented development. Journal of the Eastern Asia Society for Transportation Studies 3(4): 137-148.

Kim, J.H., F. Pagliara, and J. Preston. 2005. The intention to move and residential location choice behavior. Urban Studies 42(9): 1621-1636.

Levin, J., and A. Inam. 2004. The market for transportation-land use integration: Do developers want smarter growth than regulations allow? Transportation 31(3): 409-427.

Lin, J.J., and C.C. Gau. 2006. A TOD planning model to review the regulation of allowable development densities around subway stations. Land Use Policy 23(3): 353-360.

Lin, J.J, and C.N. Li. 2008. A grey programming model for regional transit-oriented development planning. Papers in Regional Science 87(1): 119-139.

Lin, J.J., and T.Y. Shin. 2008. Does transit-oriented development affect metro ridership? Evidence from Taipei. Transportation Research Record: Journal of Transportation Research Board 2063: 149-158.

Loukaito-Sideris, A. 2000. Transit-oriented development in the inner city: A Delphi survey. Journal of Public Transportation 3(3): 75-98.

Lund, H. 2006. Reasons for living in a transit-oriented development, and associated transit Use. Journal of the American Planning Association 72(3): 357-366. 
Lund, H., R. Cervero, and R.W. Willson. 2004. Travel Behavior of Transit-oriented Development in California (Final Report). Sacramento: California Department of Transportation.

Moon, H. 1990. Land use around suburban transit stations. Transportation 17(1): 67-88.

Senior, M. L., C. J. Webster and N. E. Blank. 2004. Residential preferences versus sustainable cities: Quantitative and qualitative evidence from a survey of relocating owner-occupiers. Town Planning Review 75: 337-357.

Sermona, M.W., and F.S. Koppelman. 2001. Representing the differences between female and male commute behavior in residential location choice models. Journal of Transport Geography 9: 101-110.

Srinivasan, S., and J. Ferreira. 2002. Travel behavior at the household level: Understanding linkages with residential choice. Transportation Research Part D 7: 225-242.

Wee, B., H. Holwerda, and R. Baren. 2002. Preferences for modes, residential location and travel behavior: The relevance for land-use impacts on mobility. European Journal of Transport and Infrastructure Research 2(3/4): 305-316.

White, S.M., and J.B. McDaniel. 1999. The Zoning and Real Estate Implications of Transit-Oriented Development. Transit Cooperative Research Program, Transportation Research Board, National Research Council. Washington D. C.: National Academy Press.

Zhuo, C.W. 2004. Transit-oriented Development Evaluation Model for Kaoshong Metro Station Areas. Master's degree thesis, Department of Urban Planning, National Chenkung University. (In Chinese)

\section{About the Authors}

JEN-JIA LIN (jenjia@mail.ntpu.edu.tw) is a Professor of the Graduate Institute of Urban Planning at the National Taipei University, Taipei, Taiwan. His research field is transportation and land use interactions and quantitative analysis of urban and regional development. He is the acting Editor-in-Chief of City and Planning, an official academic journal of Taiwan Institute of Urban Planning, and a member of International Science Committee of the Eastern Asia Society for Transportation Studies. 
YA-CHUN JeN (anita0301@yahoo.com.tw) provided research assistance for this study. She received her master's degree in Urban and Regional Planning from the National Taipei University and is currently a senior specialist in the National Property Administration of the Ministry of Finance in Taiwan. Her interests are theoretical and practical studies of transit-oriented development along metro systems. 